\title{
ASSESSMENT OF PHYSICAL PROPERTIES OF BRIQUETTES MADE OF MIXTURES OF SELECTED PLANT RAW MATERIALS AND POST-FERMENTATION WASTE
}

\author{
Ignacy Niedziółka*, Beata Zaklika \\ Department of Agricultural Machines Theory, University of Life Sciences in Lublin \\ "Corresponding author: e-mail: ignacy.niedziolka@up.lublin.pl
}

\begin{tabular}{|c|c|}
\hline ARTICLE INFO & ABSTRACT \\
\hline $\begin{array}{l}\text { Article history: } \\
\text { Received: August } 2015 \\
\text { Received in the revised form: } \\
\text { September } 2015 \\
\text { Accepted: October } 2015\end{array}$ & $\begin{array}{l}\text { Searching for renewable energy sources causes the increase in the } \\
\text { interest in obtaining and processing of plant biomass for energy } \\
\text { purposes. One of the methods of using biomass is to converse it into } \\
\text { solid biofuels in the form of briquettes. The research covered briquette } \\
\text { production with the use of the following plant raw materials: straw of }\end{array}$ \\
\hline $\begin{array}{l}\text { Key words: } \\
\text { biomass, } \\
\text { post-fermentation waste, } \\
\text { briquettes, } \\
\text { density, } \\
\text { mechanical strength }\end{array}$ & $\begin{array}{l}\text { post-fermentation waste. Samples of fragmented straw with addition } \\
\text { of post-fermentation waste were prepared in three various weight } \\
\text { participation i.e.: } 90 / 10 \%, 80 / 20 \% \text { i } 50 / 50 \% \text {. The paper presents an } \\
\text { assessment of physical properties of briquettes manufactured from the } \\
\text { investigated mixtures of plant raw materials with an addition of post- } \\
\text { fermentation waste in the hydraulic piston briquetting machine. We } \\
\text { determined the moisture of raw materials and waste, length, diameter } \\
\text { and mass of manufactured briquettes as well as their specific density } \\
\text { and mechanical strength. We found out that along with the increase of } \\
\text { the mass participation of post-fermentation waste in the accepted } \\
\text { mixtures of plant materials from } 10 \text { to } 50 \% \text { their length increased from } \\
5 \text { to } 25 \% \text { and the mass from } 1 \text { to } 12 \% \text {. On the other hand, specific } \\
\text { density of briquettes increased from } 18 \text { to } 24 \% \text { for grain mixtures and } \\
\text { from } 3 \text { to } 7 \% \text { for oat straw. Mechanical strength of briquettes was } \\
\text { within } 88.3-90.6 \% \text { for grain mixture and } 83.6-87.1 \% \text { for oat straw. }\end{array}$ \\
\hline
\end{tabular}

\section{Introduction}

Around the world and in Poland, a greater emphasis is put on the use of renewable energy sources. Presently, energy from wind, solar radiation, water and geometry, and mainly from biomass is used. Followers of renewable energy sources indicate problems related to incineration of fossil fuels, which cause environment pollution, global warming and reduction of their resources (Janowicz, 2006).

Searching for alternative energy sources caused an increase of the interest in processing and obtaining biomass for energy purposes. It may be obtained from waste from agri-food industry and from annual and perennial cultivations or by-products. Surpluses and waste such as grass from permanent grasslands (hay), grain straw and straw of other plants as well 
Ignacy Niedziółka, Beata Zaklika

as energy plants from purposeful cultivations are most often used for solid biofuels production (Kołodziej and Matyka, 2012; Stolarski et al., 2008; Terlikowski, 2012).

Plant biomass is a fuel which is difficult for use and requires appropriate processing. Mainly it is a fuel with a local scope, which is often moist, non-uniform and of low energy value in comparison to the volumetric unit. Therefore, in comparison to other energy carriers, biomass seems to be a burdensome raw material with regard to energy. However, biomass enjoys constant interest of potential recipients of electric and thermal energy as well as agricultural producers and ecologists, on account of its popularity and availability. Calorific value and physical properties of produced biofuels depend on the moisture, type and degree of biomass fragmentation (Temmerman et al., 2006; Wu et al., 2011).

Non-processed plant biomass is characterized by low density; it also causes problems with transport and storing. Constant, liquid and gas biofuels are produced from biomass, which occurs itself in various physical states. Among solid biofuels there are pellets and biofuels, for production of which, various types of plant materials are used, inter alia: sawdust, bark, chips, wood chips, energy plants etc. Straw from all types of grains, rapeseed and buckwheat is mainly used. Rye, wheat, rapeseed and buckwheat straw and corn rachis are particularly valuable (Majtkowski, 2007; Piotrowski et al., 2004).

The wheat straw is basically used as fodder and litter in animal production and its surpluses are used for energy purposes. On the other hand, rapeseed, horse bean and sunflower straw are not used in animal production and therefore it is frequently obtained for production of briquettes. Such management of straw has many advantages. The produced fuel is not harmful for environment and heating is more profitable on account of its competitive prices in comparison to conventional energy sources (Grzybek, 2003; Kościk, 2007).

Post-fermentation residue from biogas station, which is harmful to environment and require relevant technology of storing and utilization, is available. Therefore, the interest not only in biogas but also in processing post-ferment for fertilization and energy purposes increases. Particularly favourable is the use of solid post-fermentation waste for pellets or briquettes. Physical properties and chemical composition of produced biofuels depend on the substrate used for biogas production (Czekała et al., 2012; Lewandowski and Ryms, 2013; Szyszlak-Bargłowicz and Piekarski, 2009).

Thus, it is necessary to search for possibilities of rational use of by-products and waste for heating purposes, consisting in production of fuel in the form of briquettes. Production of this type of fuel may be an alternative or supplementary energy source. Such use of agricultural biomass is indicated on account of environment protection (Frączek, 2010; Kallyan and Morey, 2009; Klimiuk et al., 2012; Niedziółka, 2014).

\section{Objective and scope of the study}

The paper presents the assessment of basic physical properties of briquettes manufactured from the selected mixtures of plant materials with an addition of post-fermentation waste in the hydraulic piston briquetting machine. The scope of the study covered fragmentation of the researched plant raw materials, mixing them with post-fermentation waste in the assumed mass share and then carrying out the briquetting process. 


\section{Material and research methods}

The following plant raw materials were used for research: grain mixture straw (spring wheat with spring barley $-50 / 50 \%$ ) and oat straw as well as post-fermentation waste. Samples from fragmented raw materials were prepared in three various mass shares i.e. grain mixture and post-fermentation waste in the following composition: $90 / 10 \%, 80 / 20 \%$ and $50 / 50 \%$, oat straw and post-fermentation waste in the following composition: $90 / 10 \%$, $80 / 20 \%$ and $50 / 50 \%$. Fragmentation degree of raw materials whose length is $>3.15 \mathrm{~mm}$ was in case of grain mixture $75.5 \%$ of the sample mass and for oat straw it was $83.2 \%$. And for post-fermentation waste the fragmentation degree was $55.8 \%$ of the sample mass with the length of $<3.15 \mathrm{~mm}$. For production of briquettes a hydraulic piston briquetting machine JUNIOR type by DETA Polska was used. Working pressure of a briquetting machine was $8 \mathrm{MPa}$.

Specific moisture of raw materials was determined with the use of a laboratory moisture balance MAX 50/1/WH by RADWAG. Samples of moist biomass (approx. $5 \mathrm{~g}$ ) were placed in the drying chamber of the moisture balance and then dried in the temperature of $120^{\circ} \mathrm{C}$ to the moment of achieving constant mass. The value of moisture value of the dried raw material was read from the screen.

Water mass necessary to receive the required moisture of raw material was calculated from the formula (1):

$$
\mathrm{m}_{\mathrm{w}}=\frac{\mathrm{w}_{2}-\mathrm{w}_{1}}{100-\mathrm{w}_{2}} \cdot \mathrm{m}_{\mathrm{n}} \quad(\mathrm{g})
$$

where:

$\mathrm{m}_{\mathrm{w}}$ - water mass for hydration, $(\mathrm{g})$

$\mathrm{w}_{2}$ - required moisture of raw material, (\%)

$\mathrm{w}_{1}$ - initial moisture of raw material, $(\%)$

$\mathrm{m}_{\mathrm{n}}$ - mass of the moistened raw material, $(\mathrm{g})$

For briquettes produced in the piston briquetting machine measurements of physical properties included: diameter, length and mass. For measurements samples of briquettes with the mass of $1000 \mathrm{~g} \pm 10 \mathrm{~g}$ were collected and carried out in 3 iterations. We determine the geometric dimensions of briquettes with the use of a calliper with a precision of the measurement of $\pm 1 \mathrm{~mm}$, and their mass with the use of a laboratory scale with the measurement precision of $\pm 0.1 \mathrm{~g}$.

Specific density of briquettes was determined based on the measurements of physical properties of the agglomerate sample with the mass of $1000 \mathrm{~g} \pm 10 \mathrm{~g}$, made in 3 iterations and calculated according to the following formula (2)

$$
\rho_{w}=\frac{4 \cdot 10^{6} \cdot \mathrm{m}}{\pi \cdot d^{2} \cdot l}\left(\mathrm{~kg} \cdot \mathrm{m}^{-3}\right)
$$

where:

$\rho_{\mathrm{w}} \quad$ - specific density of briquette, $\left(\mathrm{kg} \cdot \mathrm{m}^{-3}\right)$

$\mathrm{m}$ - briquette mass, $(\mathrm{g})$

d - external diameter of a briquette, $(\mathrm{mm})$

1 - briquette length, $(\mathrm{mm})$ 
Ignacy Niedziółka, Beata Zaklika

We carried out measurements of mechanical strength of briquettes on the research stand according to the standard PN-EN 15210-2:2011. Rotational speed of the drum was 21 $\operatorname{rot} \cdot \mathrm{min}^{-1}\left( \pm 0.1 \mathrm{rot} \cdot \mathrm{min}^{-1}\right)$, test time $5 \mathrm{~min}$ and the mass of a sample $2000 \mathrm{~g}( \pm 100 \mathrm{~g})$. After the strength test, briquettes samples were sieved on the sieve with the meshes diameter of $31.5 \mathrm{~mm}$. Mechanical strength of briquettes was determined according to the formula (3):

$$
\mathrm{D}_{\mathrm{U}}=\frac{\mathrm{m}_{\mathrm{A}}}{\mathrm{m}_{\mathrm{E}}} \cdot 100(\%)
$$

where:

$\mathrm{D}_{\mathrm{U}}$ - mechanical strength of briquettes, (\%)

$\mathrm{m}_{\mathrm{A}}-$ mass of briquettes after the strength test, $(\mathrm{g})$

$\mathrm{m}_{\mathrm{E}}-$ mass of briquettes before the strength test, $(\mathrm{g})$

Results of measurements of physical properties of the researched briquettes were subjected to statistical analysis with the use of one-factor analysis of variance in the STATISTICA 10.0 programme. Significance of differences between averages were determined with the use of Tukey's test at the level of significance of $\alpha=0.05$.

\section{Research results and their analysis}

Table 1 presents results of the research on the moisture of raw materials and postfermentation waste. Initial moisture of raw materials was at the same level and amounted to $7.1-7.2 \%$ while after they were hydrated it was $17.1 \%$ for grain mixture and $16.9 \%$ for oat straw. Due to difficulties related to mixing of moist post-fermentation waste with plant raw materials they were dried to the moisture of $9.0 \%$.

Table 1.

Moisture of raw materials and post-fermentation waste

\begin{tabular}{lcc}
\hline Type & \multicolumn{2}{c}{ Initial (\%) } \\
\cline { 2 - 3 } of raw materials & Moisture, $\mathrm{w}_{1}$ & After hydration, $\mathrm{w}_{2}$ \\
\hline Grain mixture & 7.1 & 17.1 \\
Oat straw & 7.2 & 16.9 \\
Post-fermentation waste & 65.6 & $9,0^{* /}$ \\
\hline${ }^{*}$ - moisture of waste after drying & &
\end{tabular}

Table 2 presents results of measurements of length and mass of the produced briquettes. Average length of briquettes produced from the grain mixture with addition of postfermentation waste was within 24.2 to $29.1 \mathrm{~mm}$. While, average length of briquette produced from the oat straw with addition of post-fermentation waste was within 38.3 to 48.1 $\mathrm{mm}$. External diameter of briquettes was permanent and was $50 \mathrm{~mm}$. Average mass of briquette produced from the grain mixture with addition of post-fermentation waste was within 42.5 to $44.6 \mathrm{~g}$. Whereas the average mass of briquettes produced from oat straw with addition of post-fermentation waste was within 65.8 to $73.8 \mathrm{~g}$. 
Assessment of physical properties...

Along with the increase of the post-fermentation waste share in briquettes produced from the grain mixture their length increased from 5 to $20 \%$ and the mass from 1 to $5 \%$. On the other hand, the increase of post-fermentation waste in briquettes from oat straw caused increase of their length from 5 to $25 \%$ and mass from 3 to $12 \%$. Statistically significant differences were determined for the length of briquettes produced from the grain mixture and post-fermentation waste in the composition of $90 / 10 \%$ and $80 / 20 \%$ and $50 / 50 \%$ as well as between the length of briquettes made of oat straw and post-fermentation waste in the composition of $90 / 10 \%$ and $80 / 20 \%$ and $50 / 50 \%$. Contrary, statistically significant differences were reported for the mass of briquettes produced from the grain mixture and postfermentation waste and the mass of briquettes made of oat straw and those waste. The analysis of the length and mass of briquettes prove that the addition of post-fermentation waste to compacted raw materials favourably influenced the researched parameters.

Table 2.

The list of results of the length and mass of produced briquettes

\begin{tabular}{lcc}
\hline $\begin{array}{l}\text { Types } \\
\text { of mixtures }\end{array}$ & $\begin{array}{c}\text { Average length } \\
\text { of a briquette }(\mathrm{mm})\end{array}$ & $\begin{array}{c}\text { Average mass } \\
\text { of a briquette }(\mathrm{g})\end{array}$ \\
\hline Grain mixture and post-fermentation waste $-(90 / 10 \%)$ & $24.2 \mathrm{a}$ & $42.5 \mathrm{a}$ \\
\hline Grain mixture and post-fermentation waste $-(80 / 20 \%)$ & $25.4 \mathrm{a}$ & $42.8 \mathrm{a}$ \\
\hline Grain mixture and post-fermentation waste $-(50 / 50 \%)$ & $29.1 \mathrm{~b}$ & $44.6 \mathrm{a}$ \\
\hline Oat straw and post-fermentation waste $-(90 / 10 \%)$ & $38.3 \mathrm{c}$ & $65.8 \mathrm{~b}$ \\
\hline Oat straw and post-fermentation waste $-(80 / 20 \%)$ & $40.4 \mathrm{c}$ & $67.9 \mathrm{~b}$ \\
\hline Oat straw and post-fermentation waste $-(50 / 50 \%)$ & $48.1 \mathrm{~d}$ & $73.8 \mathrm{~b}$ \\
\hline NIR & 3.77 & 8.62 \\
\hline a, b, c $\ldots$ - averages marked with the same letter do not differ significantly at the level of $\alpha=0.05$ &
\end{tabular}

Figures 1 and 2 present briquettes produced from the researched plant raw materials and post fermentation waste.

Specific density of briquettes produced from the grain mixture with addition of postfermentation waste was within $727-902 \mathrm{~kg} \cdot \mathrm{m}^{-3}$. Whereas the specific density of briquettes produced from oat straw and post-fermentation waste was within $882-940 \mathrm{~kg} \cdot \mathrm{m}^{-3}$ (fig. 3). Based on the statistical analysis, significant differences were reported for the specific density of briquettes from the grain mixture and post-fermentation waste in the composition of $90 / 10 \%$ and density of the remaining briquettes produced from the assumed composition of mixtures and post-fermentation waste and for specific density of briquettes from the grain mixture and post-fermentation waste in the composition of $80 / 20 \%$ and density of briquettes from oat straw and post-fermentation waste at the mass share of $50 / 50 \%$. We did not report any statistically significant differences between the density of briquettes from the grain straw mixture and post-fermentation waste in the composition of $80 / 20 \%$ and $50 / 50 \%$, and the density of briquettes made of oat straw and post-fermentation waste in the composition of $90 / 10 \%$ and $80 / 20 \%$. Similar relations occurred between the density of briquettes made of grain straw and post-fermentation waste in the composition of $50 / 50 \%$, and the density of briquettes made of oat straw and post-fermentation waste for mass share of $90 / 10 \%, 80 / 20 \%$ and $50 / 50 \%$. 
Ignacy Niedziółka, Beata Zaklika

a)

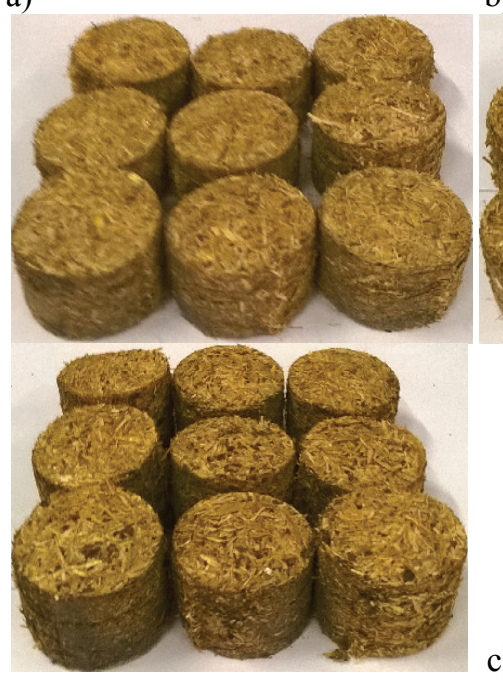

b)

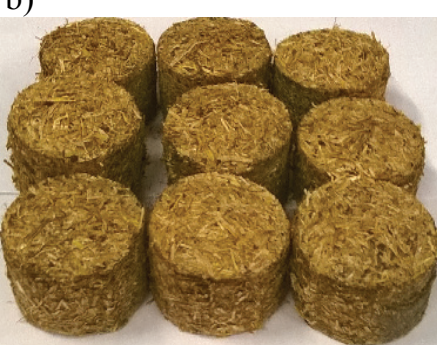

c)

Figure 1. Briquettes produced from the grain mixture and post-fermentation waste for accepted mass share: a) - 90/10\%, b) - 80/20\%, c) $-50 / 50 \%$

a)

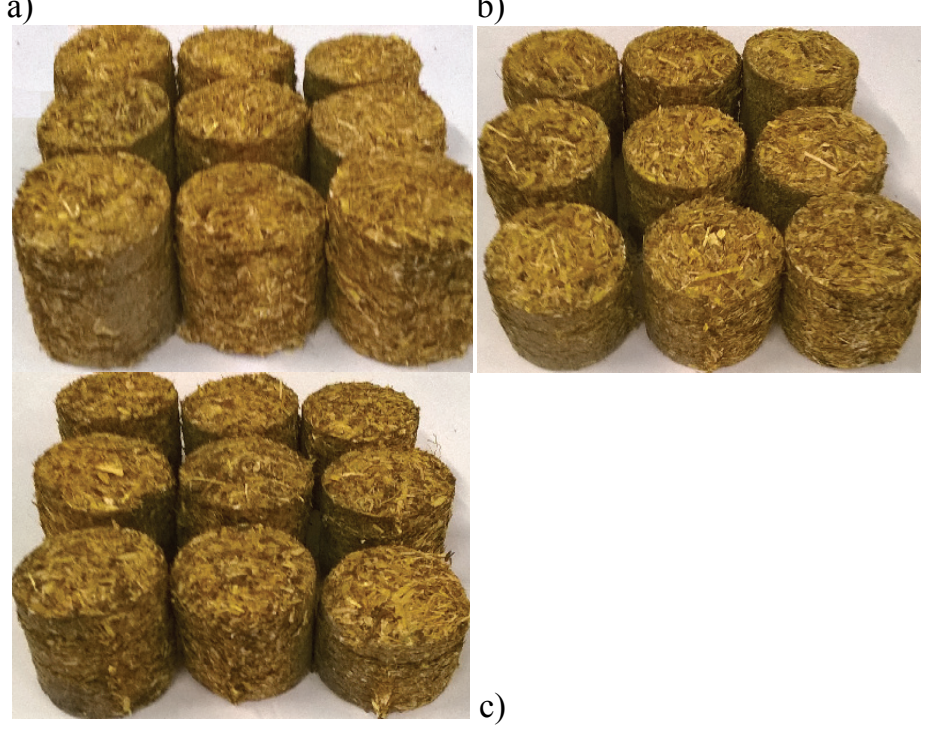

Figure 2. Briquettes produced from oat straw and post-fermentation waste for accepted mass share: a) $-90 / 10 \%$, b) $-80 / 20 \%$, c) $-50 / 50 \%$ 
Assessment of physical properties...

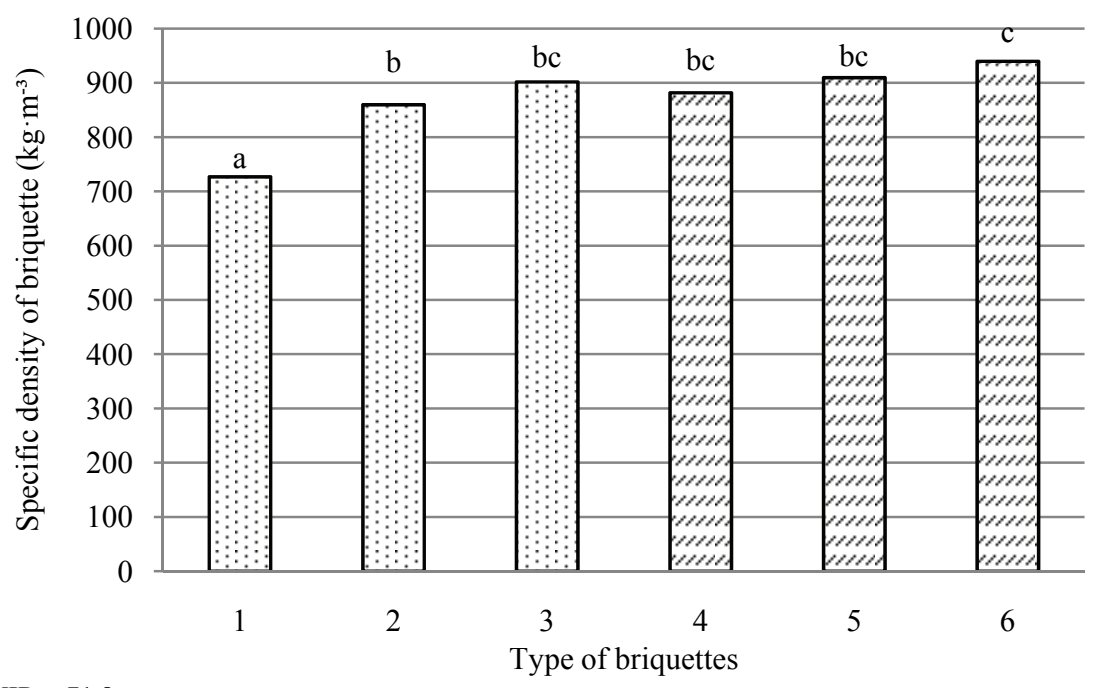

$\mathrm{NIR}=71.8$

$\mathrm{a}, \mathrm{b}, \mathrm{c} \ldots-$ arithmetic averages denoted with the same letter do not differ significantly at the level of $\alpha=0.05$

Figure 3. Specific density of briquettes produced from the grain mixture and postfermentation waste in the following composition: $1-90 / 10 \%, 2-80 / 20 \%, 3-50 / 50 \%$ and the oat straw and post-fermentation waste in the following composition: $4-90 / 10 \%$, $5-80 / 20 \%, 6-50 / 50 \%$

Figure 4 presents the results of the research on the mechanical strength of briquettes. Mechanical strength of briquettes produced from the grain mixture with addition of postfermentation waste was within $88.3-91.3 \%$ whereas in case of briquettes produced from oat straw with an addition of post-fermentation waste it was within $83.6-87.1 \%$. Statistically significant differences were reported for the mechanical strength of briquettes produced from the grain mixture and post-fermentation waste in the composition of $80 / 20 \%$ and $50 / 50 \%$ and the strength of briquettes from oat straw with an addition of post-fermentation waste in the composition of $90 / 10 \%$. In the remaining cases, we did not report any statistically significant differences between the mechanical strength of briquettes produced from those raw materials.

Based on the obtained results of research, one may state that the addition of postfermentation waste for the used plant materials in the accepted mass shares favourably influenced the researched physical properties of briquettes. Along with the increase of the share of post-fermentation waste higher parameters of the studied properties were obtained. More advantageous effects with regard to length, mass and specific density were obtained for briquettes produced from the oat straw mixtures and post-fermentation waste in comparison to briquettes produced from the grain straw mixture and used waste. Only in case of mechanical strength higher parameters were reported for briquettes made of grain straw mixture and post-fermentation waste in comparison to briquettes made of the oat straw mixture and used waste. Their improvement was influenced by a finer fraction of post- 
Ignacy Niedziółka, Beata Zaklika

fermentation waste in comparison to fragmented plant raw materials. It is confirmed by results of research of other authors, which say that participation of finer fractions allows obtaining a product of the highest endurance (Fiszer, 2008; Hebda and Złobecki, 2012).

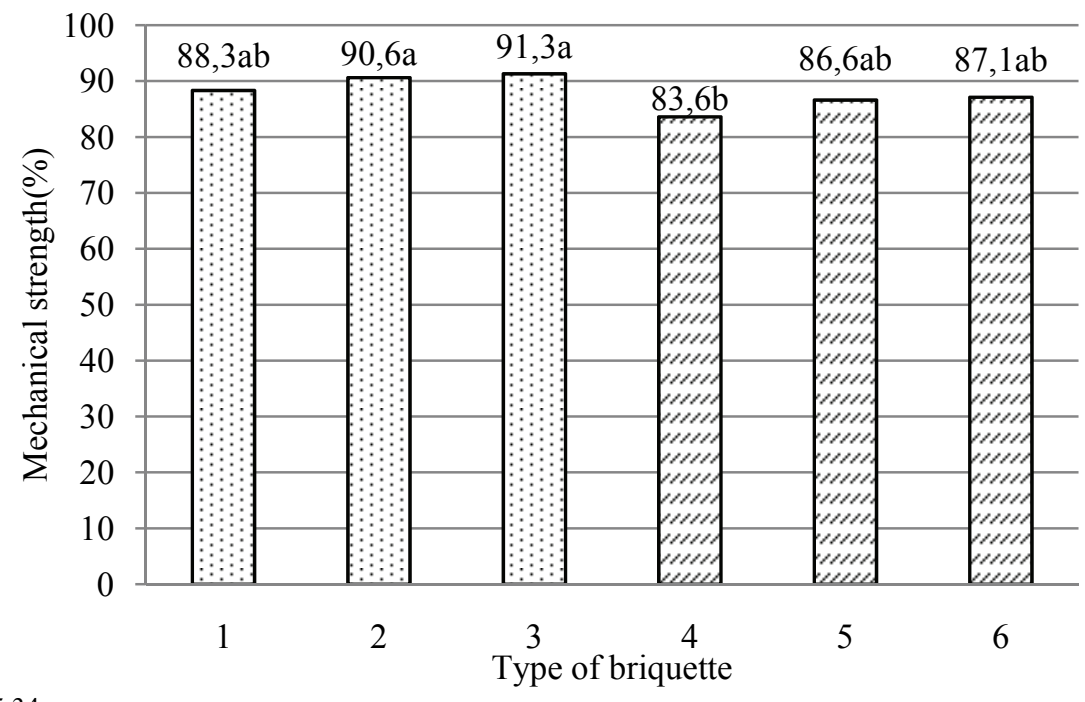

$\mathrm{NIR}=5.34$

$\mathrm{a}, \mathrm{b}, \mathrm{c} \ldots$ - averages marked with the same letter do not differ significantly at the level of $\alpha=0.05$

Figure 4. Mechanical strength of briquettes produced from the grain mixture and post-fermentation waste in the following composition: $1-90 / 10 \%, 2-80 / 20 \%, 3-50 / 50 \%$ and the oat straw and post-fermentation waste in the following composition: $4-90 / 10 \%$, $5-80 / 20 \%, 6-50 / 50 \%$

\section{Conclusions}

Based on the research, which was carried out and based on the obtained results, we made the following conclusions:

1. Briquettes produced from the mixtures of agglomerated plant raw materials and postfermentation waste had favourable parameters concerning the investigated physical properties as well as specific density and mechanical strength.

2. Briquettes produced from the grain mixture and post-fermentation waste in the composition of $90 / 10 \%$ were the shortest $(24.2 \mathrm{~mm})$ and had the lowest mass $(42.5 \mathrm{~g})$ and briquettes produced from the oat straw mixture and waste in the composition of 50/50\% were the longest $(48.1 \mathrm{~mm})$ and their mass was $(73.8 \mathrm{~g})$.

3. Along with the participation of post-fermentation waste in the compacted plant raw materials their length increased by $5-20 \%$ and their mass by $1-5 \%$ in case of briquettes from the grain mixture and respectively by $5-25 \%$ and by $3-12 \%$ in case of briquettes made of oat straw. 
Assessment of physical properties...

4. Briquettes made of grain mixture and post-fermentation waste in the composition of $90 / 10 \%$ had the lowest specific density $\left(727 \mathrm{~kg} \cdot \mathrm{m}^{-3}\right)$ and briquettes made of oat straw and post-fermentation waste in the composition of $50 / 50 \%$ had the highest specific density $\left(940 \mathrm{~kg} \cdot \mathrm{m}^{-3}\right)$.

5. The lowest mechanical strength (83.6\%) was obtained for briquettes made of oat straw and post-fermentation waste in the composition of $90 / 10 \%$ and the highest strength $(91.3 \%)$ was reported in case of briquettes produced from the grain mixture and postfermentation waste in the composition of 50/50\%.

\section{References}

Czekała, W., Pilarski, K., Dach, J., Janczak, D., Szymańska, M. (2012). Analiza możliwości zagospodarowania pofermentu z biogazowni. Technika Rolnicza Ogrodnicza Leśna, 4, 13-15.

Fiszer, A.(2008). Badania porównawcze współczynnika trwałości brykietów ze słomy. Journal of Research and Applications in Agricultural Engineering, 53(3), 69-71.

Frączek, J.(red.). (2010). Przetwarzanie biomasy na cele energetyczne. Wyd. PTIR Kraków, ISBN 978-83-917053-9-1.

Grzybek, A. (2003). Kierunki zagospodarowania biomasy na cele energetyczne. Wieś Jutra, 9(62), $10-11$.

Hebda, T., Złobecki A. (2012). Wpływ stopnia rozdrobnienia słomy na trwałość kinetyczną brykietów. Inżynieria Rolnicza, 2(137), T. 2, 57-64.

Janowicz, L. (2006). Biomasa w Polsce. Energetyka i Ekologia, 8, 601-604.

Kallyan, N., Morey R.V. (2009). Factors affecting strength and durability of densified biomass products. Biomass and Bioenergy, 33, 337-359.

Klimiuk, E., Pawłowska, M., Pokój, T. (2012). Biopaliwa. Technologie dla zrównoważonego rozwoju. PWN, ISBN 978-83-01-17170-4.

Kołodziej, B., Matyka, M.(red.). (2012). Odnawialne źródła energii. Rolnicze surowce energetyczne. PWRiL Sp. z o.o. Poznań, ISBN 978-83-09-01139-2.

Kościk, B. (2007). Surowce energetyczne pochodzenia rolniczego. Wyd. Nauk. PWSZ Jarosław, ISBN 978-83-88139-61-1.

Lewandowski, W.M., Ryms, M. (2013). Biopaliwa. Proekologiczne odnawialne źródła energii. Wyd. WNT Warszawa, ISBN 978-83-63623-73-9.

Majtkowski, W. (2007). Rośliny energetyczne na paliwo stałe. Wieś Jutra, 8/9, 16-18.

Niedziółka I.(red.). (2014). Technika produkcji brykietów z biomasy roślinnej. Tow. Wyd. Nauk. LIBROPOLIS, ISBN 978-83-63761-38-7.

Piotrowski, K., Wiltowski, T., Mondal, K. (2004). Biomasa - kłopotliwe pozostałości czy strategiczne rezerwy czystej energii? Cz. II. Czysta Energia, 11(37), 16-18.

Stolarski, M., Szczukowski, S., Tworkowski, J. (2008). Biopaliwa z biomasy wieloletnich roślin energetycznych. Energetyka, 1, 77-80.

Szyszlak-Bargłowicz, J., Piekarski,W. (2009). Charakterystyka biomasy jako paliwa. Rozdz.w monografii pt. Biomasa jako źródło energii. Wyd. Wieś Jutra, 29-38.

Temmerman, M., Rabier, F., Daugbjerg Jensen, P., Hartmann, H., Böhm, T. (2006).Comparative study of durability test methods for pellets and briquettes. Biomass and Bioenergy, 30, 964-972.

Terlikowski, J.(2012). Biomasa z trwałych użytków zielonych jako źródło energii odnawialnej. Problemy Inżynierii Rolniczej, 1(75), 43-49.

Wu, M.R., Schott, D.L., Lodewijks, G. (2011). Physical properties of solid biomass. Biomass and Bioenergy, 35, 2093-2105. 
Ignacy Niedziółka, Beata Zaklika

\section{OCENA CECH FIZYCZNYCH BRYKIETÓW WYTWORZONYCH Z MIESZANEK WYBRANYCH SUROWCÓW ROŚLINNYCH I ODPADÓW POFERMENTACYJNYCH}

Streszczenie. Poszukiwanie odnawialnych źródeł energii powoduje wzrost zainteresowania pozyskiwaniem oraz przetwarzaniem biomasy roślinnej na cele energetyczne. Jednym ze sposobów wykorzystania biomasy jest jej konwersja na biopaliwa stałe w postaci brykietów. Badania obejmowały produkcję brykietów z wykorzystaniem następujących surowców roślinnych: słomę mieszanki zbóż jarych (pszenica z jęczmieniem - 50/50\%) i słomę owsianą oraz odpady pofermentacyjne. Próby rozdrobnionej słomy $\mathrm{z}$ dodatkiem odpadów pofermentacyjnych przygotowano $\mathrm{w}$ trzech różnych udziałach masowych tj.: 90/10\%, 80/20\% i 50/50\%. W pracy przedstawiono ocenę fizycznych cech brykietów wytworzonych z badanych mieszanek surowców roślinnych z dodatkiem odpadów pofermentacyjnych w brykieciarce hydraulicznej tłokowej. Określano wilgotność surowców i odpadów oraz długość, średnicę i masę produkowanych brykietów, a także ich gęstość właściwą i wytrzymałość mechaniczną. Stwierdzono, że ze zwiększaniem udziału masowego odpadów pofermentacyjnych w przyjętych mieszankach surowców roślinnych od 10 do $50 \%$, wzrastała ich długość od 5 do $25 \%$ oraz masa od 1 do $12 \%$. Natomiast gęstość właściwa brykietu zwiększała się od 18 do $24 \%$ dla mieszanki zbożowej i od 3 do $7 \%$ dla słomy owsianej. Wytrzymałość mechaniczna brykietów zawierała się w przedziale $88,3-90,6 \%$ dla mieszanki zbożowej i 83,6-87,1\% dla słomy owsianej.

Słowa kluczowe: biomasa, odpady pofermentacyjne, brykiety, gęstość, wytrzymałość mechaniczna 